Pawel CzAPlińsKi

Akademia Pomorska, Słupsk

\title{
Wpływ procesów transformacji na lokalne struktury przemysłu na przykładzie byłego województwa słupskiego
}

Przemysł, uważany za kluczowy element wzrostu i rozwoju jest tym sektorem gospodarki, w którym skutki procesów transformacji systemu gospodarczego bywają szczególnie widoczne, a sam proces adaptacji do reguł wolnego rynku przebiega bardzo dynamicznie.

Analiza dotychczasowego stanu przebudowy struktur przemysłowych pozwala na stwierdzenie, iż poza niezbędnymi nakładami inwestycyjnymi oraz narzędziami natury prawno-administracyjnej, dla samego procesu, a także dla pełnej i obiektywnej oceny zachodzących zmian potrzebny jest odpowiednio długi horyzont czasowy [Makieła 2000]. Motyw potrzebnego czasu jest także szczególnie ważny przy rozważaniach nad rozwojem przemysłu w perspektywie strategicznej, gdzie jako element sterujący pojawia się makrorestrukturyzacja. Makrorestrukturyzacja rozumiana jako: ,proces, w którym państwo lub inny podmiot zewnętrzny za pomocą różnych instrumentów aktywnie działa w kierunku przyśpieszania rozwoju produkcji określonych wyrobów, rodzajów produkcji, branż lub gałęzi przemysłu" [Mikołajewicz 1995], a kojarzona czasami z polityką przemysłową państwa, winna w pierwszym rzędzie stymulować rozwój wybranych kierunków produkcji w uzyskiwaniu konkurencyjności na rynku europejskim, a nawet światowym [Pełka 1998].

$\mathrm{Z}$ badań przeprowadzonych nad przystosowaniem polskich przedsiębiorstw przemysłowych do wymogów UE wynika jednak, że barierą w procesie dostosowań jest nie tylko słaba kondycja ekonomiczna jednostek produkcyjnych (określana jako bariera kapitałowa) czy niekorzystna struktura uniemożliwiająca znaczną ekspansję eksportową, lecz nikła świadomość skutków procesu integracyjnego [Kukliński 1995; Zioło 1997].

Jak piszą E. Rydz, I. Jażewicz [1994a]: ,,przemiany w funkcjonowaniu przedsiębiorstw w nowych warunkach systemowo-ustrojowych polegają na przekształceniach własnościowych". Podejmując więc problematykę transformacji przemysłu, należy także zwrócić uwagę na proces prywatyzacji majątku, który poza wymiarem czysto ekonomicznym, związanym z poprawą efektywności działalności, ma także wymiar społeczny, gdyż społeczne koszty przekształcenia sektora państwowego w sektor prywatny zależą m.in. od wyboru ścieżki prywatyzacji, co z kolei ma znaczenie dla układów lokalnych i regionalnych. Zmiany w strukturze własnościowej przemysłu ukierunkowane na rozwój sektora prywatnego (który uznaje się za siłę motoryczną rozwoju, a zarazem jeden z podstawowych celów transformacji) wiążą się nie tylko ze zmianą struktury wielkościowej przedsiębiorstw, ale także z rolą i funkcją 
kapitału zagranicznego w kształtowaniu nowej przestrzeni przemysłowej, objawiającej się postępującą internacjonalizacją i globalizacją produkcji [Zioło 1997; 2000].

W świetle wszystkich powyższych faktów za istotne uznano przedstawienie wpływu procesu transformacji systemowej na układy przestrzenne przemysłu na obszarze byłego województwa słupskiego, które od 1999 r. (zwłaszcza w zestawieniach statystycznych) stanowi część województwa pomorskiego (ryc. 1).

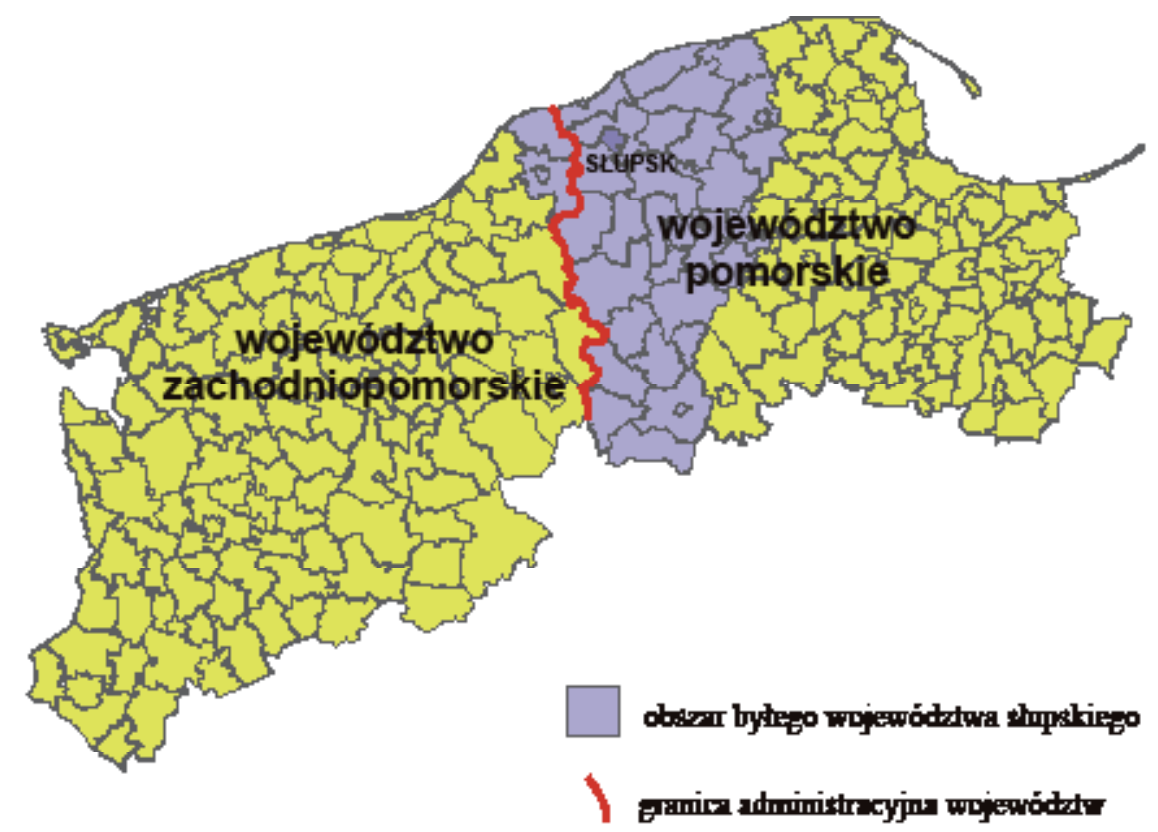

Ryc. 1. Obszar byłego województwa słupskiego na tle aktualnego podziału administracyjnego kraju

Źródło: Opracowanie własne

Podkreślić należy, że przemysł województwa słupskiego u progu zmian systemowych, cechowała silna koncentracja w miastach, która bazowała przede wszystkim na tradycyjnych gałęziach przemysłu (przemysł drzewny, skórzano-obuwniczy, spożywczy). Produkcja przemysłowa ogółem stanowiła zaledwie $0,7 \%$ produkcji przemysłowej w skali kraju. Przemysł był jednak ważnym źródłem utrzymania ludności, dawał bowiem zatrudnienie dla około 25\% pracujących [Rydz, Jażewicz 1994a,b].

Od połowy 1989 r., tj. od zainicjowania procesu urynkowienia gospodarki, obserwuje się wyraźne zmiany w przemyśle województwa słupskiego spowodowane głównie transformacją gospodarczą. Analiza wielkości produkcji przemysłowej, zatrudnienia oraz liczby podmiotów gospodarczych pozwoliła wyróżnić trzy etapy transformacji struktur przemysłowych.

Pierwszy etap, który polegał na reakcji obronnej wobec szoku systemowego (lata 19891992), charakteryzował się:

- wzrostem liczby zakładów sektora prywatnego,

- wzrostem liczby zakładów sektora publicznego,

- gwałtownym spadkiem produkcji przemysłowej,

- spadkiem wielkości zatrudnienia. 
W drugim etapie transformacji, przypadającym na lata 1993-1997, następowało przełamywanie recesji. Jego charakterystyczne cechy to:

- wzrost zatrudnienia w sektorze prywatnym,

- redukcja zatrudnienia w sektorze publicznym,

- duża liczba nowych zakładów sektora prywatnego,

- wzrost produkcji w sektorze prywatnym.

Trzeci etap, określany mianem stagnacji, rozpoczął się w 1998 r., a jego oznaki widoczne były do końca 2003 r. Charakteryzował się on generalnie spadkiem liczby pracujących w przemyśle, co wynikało z wszczętych wcześniej procesów restrukturyzacji i prywatyzacji majątku państwowego, a także ze spadku zatrudnienia w sektorze prywatnym, gdzie na skutek niekorzystnych warunków w otoczeniu prawno-finansowym dokonywano redukcji kosztów poprzez m.in. ograniczanie zatrudnienia i wygaszanie produkcji. Zjawisko to przyczyniło się do upadłości największego pod względem zatrudnienia podmiotu produkcyjnego Lęborka, jakim były Zakłady Wytwórcze Aparatury Rozdzielczej „ABB-Zwar” SA. Podobne zjawisko miało miejsce w Sławnie, gdzie likwidacji uległy zakłady drzewne „Sławodrzew”.

Jak już wcześniej ustalono, w latach transformacji systemu gospodarowania w podregionie słupskim można wyróżnić trzy zasadnicze fazy rozwoju przemysłu, w których przemysł odmiennie reagował na nowe, zmieniające się warunki otoczenia. W początkowej fazie transformacji (1989-1992), mimo dość znacznej dynamiki zatrudnienia oraz produkcji sprzedanej, dała się zaobserwować duża stabilność struktury przestrzennej, bowiem wskaźnik redystrybucji* w tym okresie wyniósł 0,150 . W następnych dwóch fazach jego wartość uległa znacznemu obniżeniu (odpowiednio 0,123 i 0,082), co sugeruje utrwalanie się dotychczasowej struktury przestrzennej przemysłu.

Analizując powyższe wyniki, można także przyjąć, że największe zmiany w strukturze przestrzennej zaszły w pierwszej fazie, a wraz z zaawansowaniem procesów transformacyjnych ich skala malała. Potwierdza to także średniookresowa dynamika zmian natężenia przemysłu (łącznie w miastach i gminach województwa słupskiego), która w latach 1997-2000 była niższa o 73,6\% niż w okresie 1988-1993.

$\mathrm{Z}$ badań jakie przeprowadzono nad strukturami przestrzennymi przemysłu w regionie słupskim wynika, że mimo tendencji do stabilizacji przestrzennej przemysłu, doszło jednak do przesunięć punktów kulminacyjnych (np. z miast w strefy podmiejskie) oraz często do okresowego wzrostu zatrudnienia w przemyśle w danej jednostce - mieście lub gminie.

W 1988 r. obraz przestrzenny charakteryzowała względna monotonia, z wyraźnymi kulminacjami w miastach, a w roku 2003 mamy do czynienia z dość dużą mozaiką uprzemysłowienia (ryc. 2).

Istnieje wyraźna koncentracja przedsiębiorstw w strefie podmiejskiej Słupska (gminy Słupsk i Kobylnica), gdzie na skutek lokalizacji nowych zakładów lub relokacji już istniejących nastapiło silne przekształcenie wsi i nadanie im funkcji technoprodukcyjnych. Istotny wpływ na rozwój przemysłu w strefie podmiejskiej ma także istnienie Słupskiej Specjalnej Strefy Ekonomicznej, w której do końca 2000 r. zezwolenia na działalność otrzymało 21

*Wskaźnik redystrybucji (D) obliczono według wzoru [Zioło 1999]:

$\mathbf{D}=\frac{\mathbf{1}}{\mathbf{2}} \mathbf{\mathbf { L }}\left|\mathrm{d}_{\mathrm{i}}{ }^{(\mathrm{to})}-\mathrm{d}_{\mathrm{i}}{ }^{(\mathrm{i})}\right|$

gdzie: d - procentowy udział zatrudnionych w przemyśle i-tej jednostki przestrzennej w stosunku do jednostki wyższego rzędu w przekrojach czasowych: $\left(\mathrm{t}_{0}\right)$ starszy okres czasowy i $\left(\mathrm{t}_{\mathrm{i}}\right)$ młodszy okres czasowy. 
małych i średnich, głównie polskich przedsiębiorstw przemysłowych o zróżnicowanym profilu produkcji. Przedłużeniem tego skupienia (wykorzystującym główne szlaki komunikacyjne) są korytarze inwestycyjne w kierunku Lęborka (gminy Damnica, Potęgowo) oraz Ustki (gmina Ustka).

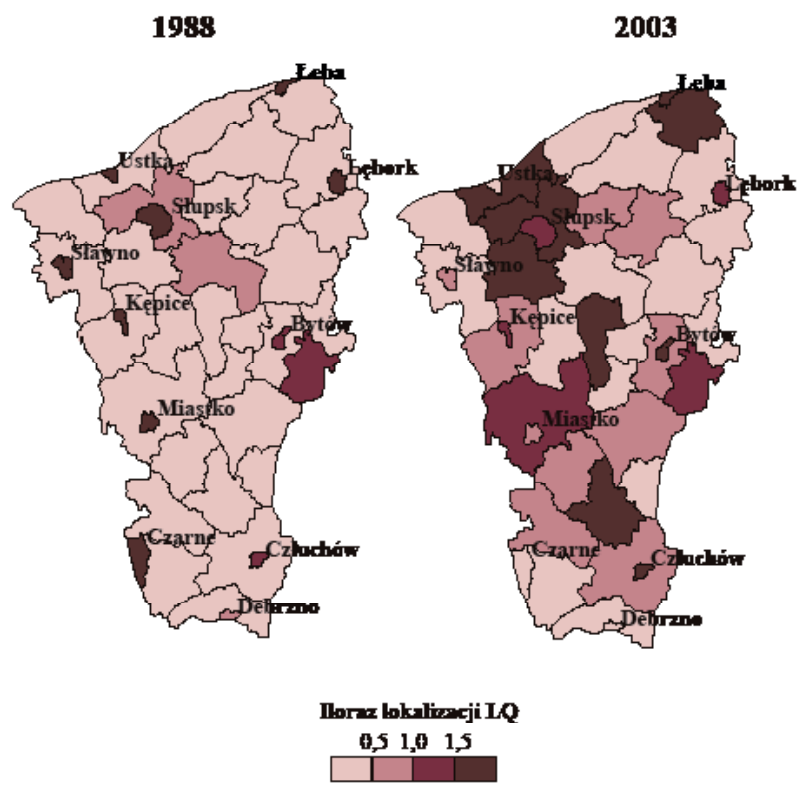

Ryc. 2. Zmiany koncentracji przestrzennej przemysłu na obszarze byłego województwa słupskiego w okresie 1988-2003 na podstawie ilorazu lokalizacji LQ

Źródło: Opracowanie własne

Specyficzny wyspowy charakter mają gminy Wicko i Kołczygłowy, gdzie nastapiło pogłębienie procesu inwestycyjnego w sferze działalności produkcyjnej, opartej na lokalnej bazie surowcowej.

Istotne skupienie inwestycji przemysłowych występuje w gminach Przechlewo, Rzeczenica i Koczała, z rosnącą rolą gminy Przechlewo. Jego podstawę stanowią (poza zakładami przerobu drewna) duże zakłady przetwórcze mięsa „Prime Food” oraz polsko-duńskie przedsiębiorstwo „Poldanor” reprezentujące przemysł paszowy.

$\mathrm{Na}$ uwagę zasługuje również ożywienie w strefach podmiejskich Bytowa i Człuchowa, gdzie dzięki wykorzystaniu kapitału zagranicznego utworzono szereg drobnych zakładów produkcyjnych o dużym stopniu specjalizacji i stosunkowo wysokim poziomie technologii (produkcja wyrobów termokurczliwych, narzędzi, części do motocykli, urządzeń hydraulicznych).

Dla uchwycenia kierunków przesunięć i dystansów pomiędzy jednostkami przestrzennymi, na bazie ilorazu koncentracji LQ* skonstruowano układ współrzędnych x, y (ryc. 3).

*Iloraz lokalizacji (LQ) opisany przez A. Kuklińskiego 1961, T. Stryjakiewicza 1999, bazuje na założeniu:

$$
\text { IQ }-\frac{\mathbf{r}}{\mathbf{r}}
$$

gdzie: $\mathrm{LQ}_{\mathrm{i}}$ - iloraz lokalizacji dla i-tej jednostki przestrzennej, $\mathrm{P}_{\mathrm{ii}}-\%$ udział i-cechy, i-tej jednostki przestrzennej w jednostce wyższego rzędu, $\mathrm{P}_{\mathrm{ji}}-\%$ udział $\mathrm{j}$-cechy, i-tej jednostki przestrzennej w jednostce wyższego rzędu. 


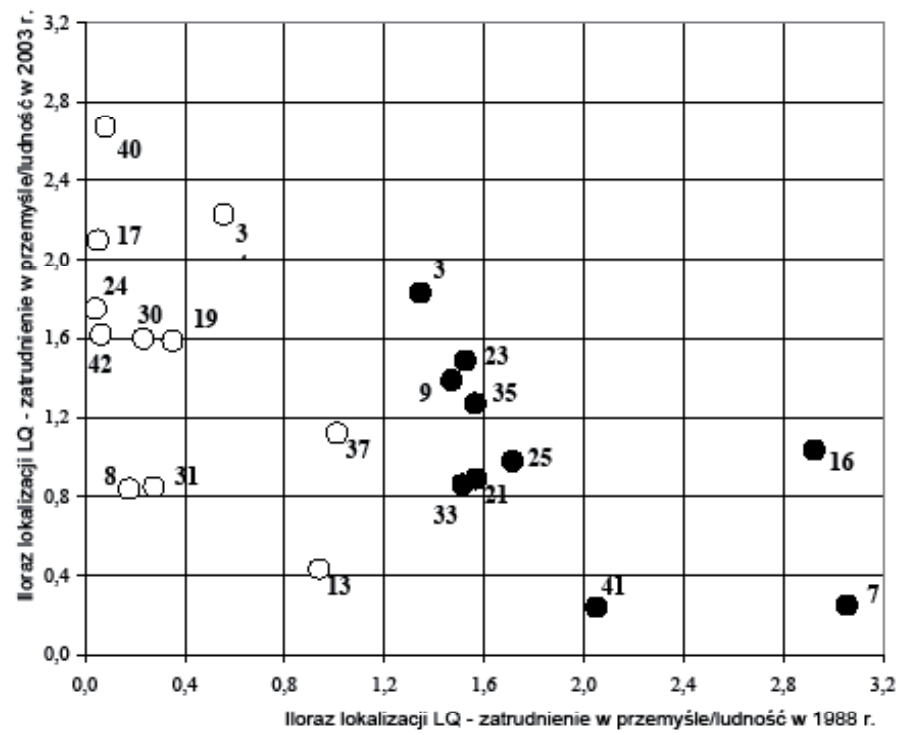

\begin{tabular}{|c|c|c|}
\hline - 3 Bytów (miasto) & - 7 Czame (miasto) & 08 Czluchów \\
\hline - 9 Człuchów (miasto) & $\square 13$ Dębnica Kaszubska & 16 Keqpice (miasto) \\
\hline 017 Kobylnica & 019 Kolczyglowy & - 21 Lębork (miasto) \\
\hline O 22 Lipnica & - 23 Leba (miasto) & O24 Miastko \\
\hline - 25 Miastko (miasto) & $\square 30$ Przechlewo & O31 Rzeczenica \\
\hline - 33 Slawno (miasto) & 口34 Slupsk & - 35 Shupsk (miasto) \\
\hline O37 Studzienice & O 40 Ustka & -41 Ustka (miasto) \\
\hline O 42 Wicko & & \\
\hline
\end{tabular}

Ryc. 3. Iloraz lokalizacji LQ - zatrudnienie w przemyśle/ludność w wybranych miastach i gminach regionu słupskiego w latach 1988 i 2003

Źródło: Opracowanie własne

W roku 1988 r. za wiodące miasta uznano Czarne i Kępice, które znacznie (o ponad 1 punkt LQ) zdystansowały pozostałe jednostki, osiagając wartości odpowiednio 3,05 i 2,92, a godne podkreślenia jest to, że w 2003 r. żadna jednostka nie przekroczyła pułapu 2,8.

Te stosunkowo małe miasta, odznaczały się dużą liczbą zatrudnionych w przemyśle, który z kolei ograniczał się zasadniczo do jednego dużego zakładu. Stworzone w ten sposób monokultury przemysłowe nie adaptowały się jednak do nowych warunków gry rynkowej, przez co ich pozycja w roku 2003 r. znacznie spadła.

Nowymi liderami w 2003 r. stały się gminy Ustka $(2,67)$, Słupsk $(2,23)$ oraz Kobylnica $(2,10)$, które startowały z bardzo niskiego pułapu, oraz Bytów $(1,83)$, który w grupie miast również nie należał do czołówki w roku 1988.

Większość miast, koncentrując się w przedziale wartości od 1,20 do 1,70, nie zmieniło zasadniczo swojej pozycji, chociaż w pojedynczych przypadkach doszło raczej do obniżenia

Iloraz lokalizacji pokazuje, w których jednostkach przestrzennych występuje „nadreprezentacja” (LQ > 1), a w których względny niedobór $(\mathrm{LQ}<1)$ danej cechy. 
miejsca w rankingu. Dotyczy to zwłaszcza Ustki, która, będąc w czołówce miast w 1988 r., na skutek właściwie upadku przemysłu stoczniowego oraz drastycznych ograniczeń w przemyśle spożywczym, zanotowała wyraźny spadek.

W latach 1989-1992, mimo zróżnicowanej na ogół dynamiki zatrudnienia w skali województwa, struktura gałęziowa przemysłu nie uległa zasadniczej przebudowie [Rydz, Zaleski 1992]. W latach 1993-2003 zaszły jednak istotne zmiany. Nastąpił bowiem spadek specjalizacji regionu dotąd identyfikowanego z przemysłem drzewnym, spożywczym oraz przemysłem skórzano-obuwniczym.

Poddając bardziej szczegółowej analizie strukturę gałęziową przemysłu na obszarze byłego województwa słupskiego, można zaobserwować zjawisko specjalizacji produkcji przemysłowej, która może jednak wynikać z różnych przesłanek (ryc. 4). Stąd wyróżniono:

- specjalizację progresywną (Bytów, Człuchów, Łeba), która wiąże się z rozwojem przemysłu i wprowadzaniem nowoczesnych profili produkcji,

- specjalizację regresywną (Sławno, Debrzno, Czarne), która jest wynikiem regresu przemysłu i powrotu do często tradycyjnych jego gałęzi.

Ponadto w wyniku przeprowadzonych badań zaobserwowano proces dywersyfikacji produkcji przemysłowej, która w szczególności dotyczy dwóch największych miast byłego województwa - Słupska i Lęborka.

1988

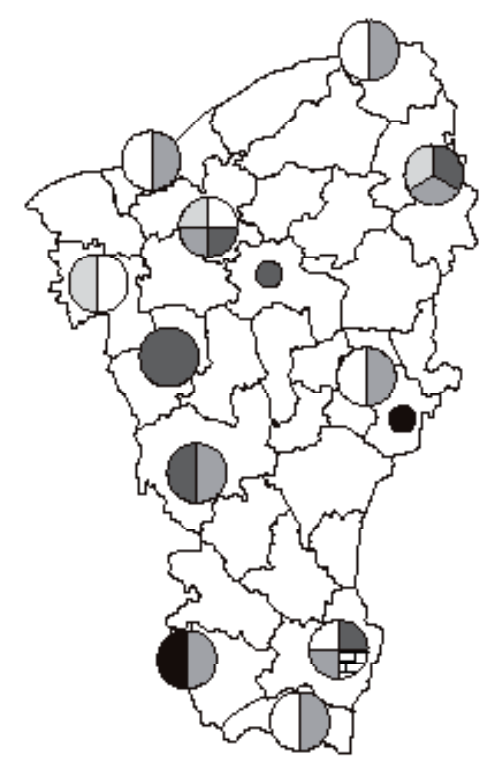

przemysł elektromaszynowy
przemysł chemiczny
przemysł mineralny
2003

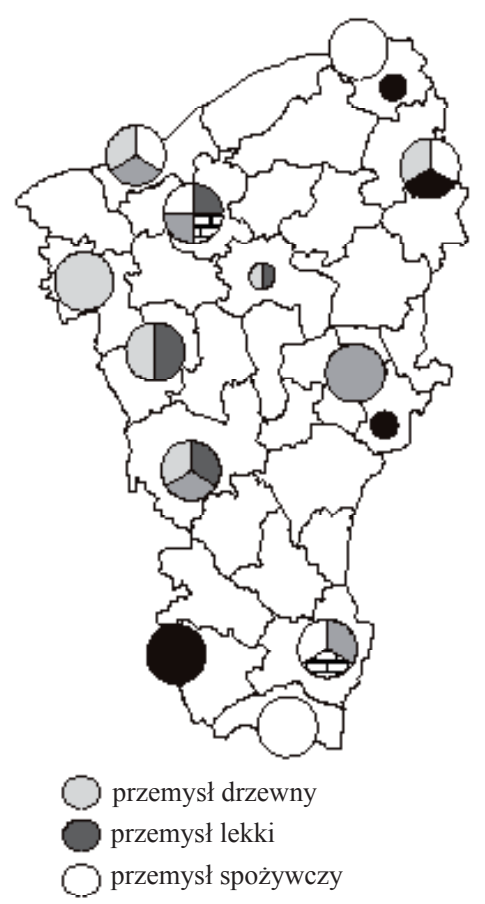

Ryc. 4. Zmiany struktury działowej przemysłu na obszarze byłego województwa słupskiego w okresie 1988-2003

Źródło: Opracowanie własne na podstawie sprawozdań P - 30 oraz badań terenowych. Uwaga: Charakter ośrodka określono na podstawie dominujących grup gałęzi przemysłu 
Rozpatrując problemy transformacji struktur przemysłowych, warto także zwrócić uwagę na element atrakcyjności inwestycyjnej analizowanego obszaru, ona to bowiem stymuluje napływ inwestorów, dzięki którym następuje przepływ zasobów (ludzi, technologii, informacji, a przede wszystkim środków pieniężnych).

Z badań jakie przeprowadzono w 2002 r. wynika, że zarówno w opinii inwestorów krajowych jak i zagranicznych jedną z najważniejszych grup czynników lokalizacji jest wsparcie instytucjonalne ze strony władz oraz otoczenie biznesu (ryc. 5). Istnieją jednak istotne różnice w ocenie pozostałych grup. Dla kapitału krajowego ważnymi okazały się także czynniki dotyczące przestrzeni do prowadzenia działalności gospodarczej. Natomiast w przypadku inwestorów zagranicznych istotnymi grupami czynników okazały się infrastruktura komunikacyjna oraz koszty produkcji. Można nawet założyć, że koszty pracy to jedna z najważniejszych przewag konkurencyjnych badanego obszaru [Czapliński 2004].

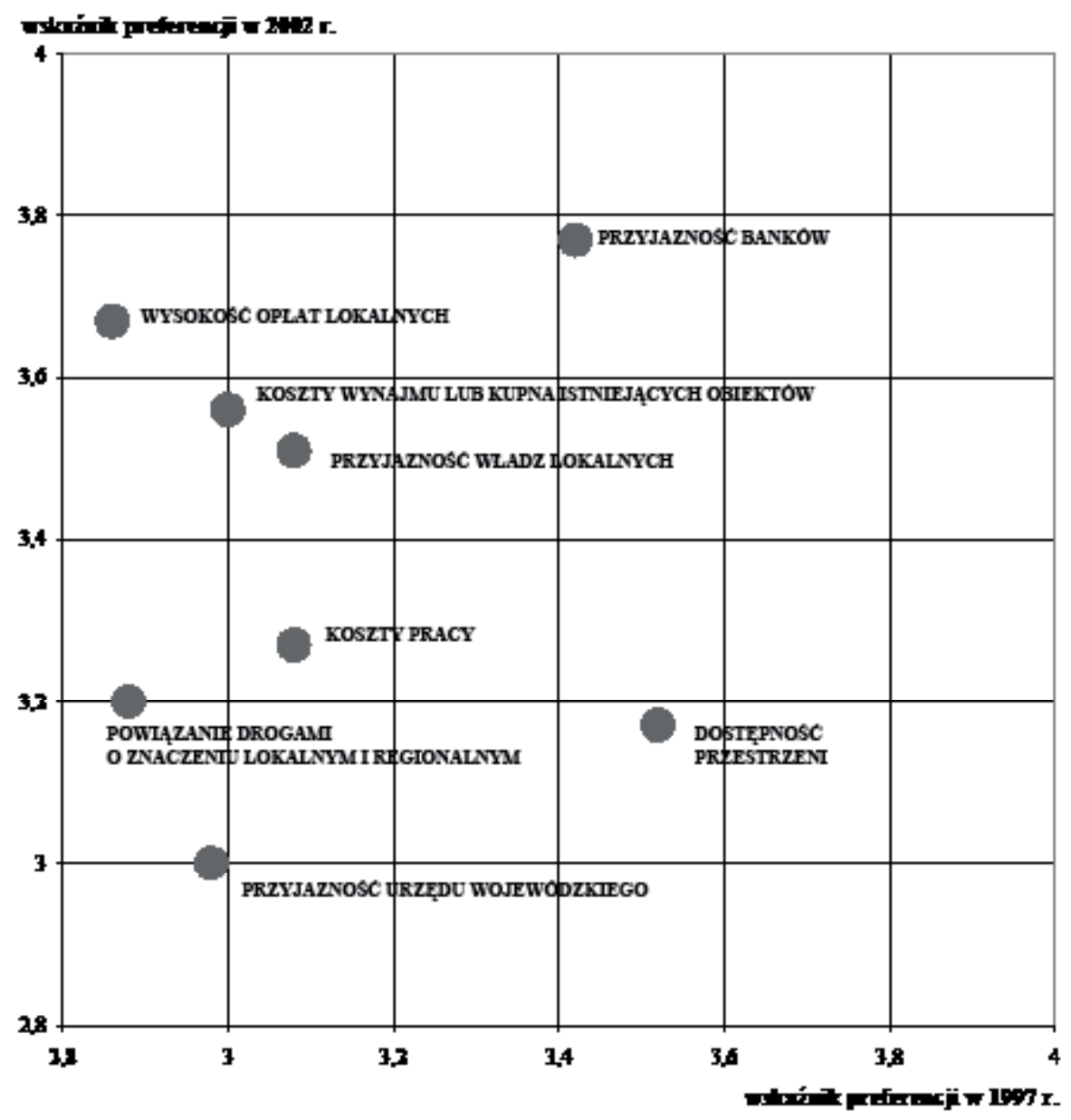

Ryc. 5. Zmiany ważności dominujących czynników lokalizacji w badaniach krajowych inwestorów na obszarze byłego województwa słupskiego w okresie 1997-2002

Źródło: Opracowanie własne 
Dokonując całościowej oceny czynników podjęcia działalności produkcyjnej, należy stwierdzić, że obszar byłego województwa słupskiego traktowany jest peryferyjne przez inwestorów, a zmiany administracyjne kraju, które miały pomóc w jego ożywieniu gospodarczym, w tym także w napływie kapitału, nie przyniosły jak dotąd zamierzonych efektów. Zabiegi władz lokalnych w celu pozyskania inwestorów ograniczają się często do działań pasywnych (np. informacje o możliwościach inwestowania), a ich siłą przetargową często pozostają niskie koszty pracy.

Jak już wspomniano, jednym z podstawowych elementów zmian strukturalnych w przemyśle jest restrukturyzacja własnościowa. Dlatego też odnosząc się do tej kwestii należy stwierdzić, że w województwie słupskim przebiegała ona w bardzo zróżnicowanym tempie. Wyniki badań wskazują, że prywatyzacja sektora państwowego bardzo ściśle odpowiada ogólnej tendencji w kraju, zastosowano przy tym wiele metod i ścieżek, ale żadna z nich nie zdominowała procesu prywatyzacji. Za najbardziej interesującą można uznać prywatyzację Fabryki Sprzętu Gospodarstwa Domowego „Zagod” w Bytowie, jako jedna z pierwszych w kraju została oparta na spółce pracowniczej, wzorcową komercjalizację i prywatyzację Północnych Zakładów Przemysłu Skórzanego „Alka” w Słupsku oraz tzw. wrogie przejęcie przez koncern Asea Brown Boveri Ltd. Zakładów Wytwórczych Aparatury Rozdzielczej „Zwar” w Lęborku [Czapliński 2003].

Reasumując, należy podkreślić, że w transformacji przemysłu obszaru byłego województwa słupskiego można wyróżnić następujące etapy:

- etap reakcji obronnej wobec szoku systemowego (1989-1992),

- etap prób przełamywania recesji (1993-1997),

- etap stagnacji (1998-).

W efekcie zmian strukturalnych doszło do osłabienia roli miast jako ważnych miejsc, skupiających przemysłowy potencjał produkcyjny. Działalność przemysłowa została skierowana na obszary podmiejskie i wiejskie, gdzie znalazła lepsze warunki ekonomiczne. Jedynie miasta Bytów, a w mniejszej skali Człuchów stały się konkurencyjne wobec inwestorów, tworząc odpowiedni klimat proinwestycyjny.

Po 1992 r. w województwie słupskim nastąpiły widoczne przekształcenia przestrzenne struktury działowej przemysłu. Tradycyjne dla regionu rodzaje przemysłu (drzewny, skórzano-obuwniczy) straciły swoją wiodącą rolę na rzecz przemysłu chemicznego (tworzyw sztucznych) oraz przemysłu elektromaszynowego.

W okresie 1997-2002 zmianie uległy preferencje lokalizacyjne. W opinii inwestorów, także zagranicznych, z obszaru byłego województwa słupskiego najważniejsze grupy czynników lokalizacji to: czynnik kosztowy, wsparcie instytucjonalne oraz dostępność komunikacyjna. Otoczenie biznesu rozwija się nierównomiernie, pogłębiając dotychczasowe różnice przestrzenne.

Proces prywatyzacji majątku państwowego, którego organem założycielskim był wojewoda słupski nie został zakończony do dnia 31 grudnia 1998 r. Wprowadzona reforma administracyjna kraju nie zakłóciła rozpoczętych już procesów. Model prywatyzacji przemysłu w województwie słupskim bardzo ściśle odpowiada ogólnej tendencji w kraju.

Podsumowując, należy jednoznacznie stwierdzić, że w przemyśle byłego województwa słupskiego w latach 1989-2000 zaszły duże zmiany i to zarówno ilościowe jak i jakościowe, a jego przyszłość z całą pewnością zależeć będzie nie tylko od możliwości efektywnego rozwoju lokalnego i regionalnego, ale także od władzy samorządowej, która jest odpowiedzialna za rozwój społeczno-gospodarczy związanych z nią obszarów. 


\section{Literatura}

Czapliński P. 2003, Ścieżki prywatyzacji przedsiębiorstw państwowych w regionie słupskim, Słupskie Prace Geograficzne, nr 1, Wydawnictwo PAP, Słupsk

Czapliński P. 2004, Czynniki podjęcia działalności produkcyjnej w podregionie stupskim, [w:] Badania geograficzne w poznawaniu środowiska, red. Z. Michalczyk, Wydawnictwo UMCS, Lublin

Kukliński A. 1961, Problemy badań nad lokalizacja poszczególnych gatęzie przemystu $w$ Polsce, Biuletyn KPZK PAN, nr 7 (9), PWN, Warszawa

Kukliński A. 1995, Europejski kontekst polskiej przestrzeni, [w:] Koncepcja polityki przestrzennego zagospodarowania kraju, red. J. Kołodziejski, t. 1, Warszawa

Makieła Z. 2000, Restrukturyzacja przemystu Polski w latach 1989-1999 (na wybranych przykladach), „Geografia w Szkole”, nr 4

Mikołajewicz Z. 1995, Procesy restrukturyzacji przemystu w regionach, Wydawnictwo UO, Opole

Pełka B., 1998, Przemyst Polski w perspektywie strategicznej, Instytut Organizacji i Zarządzania w Przemyśle „Orgmasz”, Wydawnictwo „Orgmasz”, Warszawa

Rydz E., Jażewicz I. 1994a, Przemiany struktur gatęziowo-przestrzennych przemystu województwa stupskiego w zmieniajacych się warunkach gospodarowania, [w:] Zachowanie przestrzenne przemystu w zmieniajacych się warunkach gospodarowania, red. Z. Zioło, Wydawnictwo Naukowe WSP, Warszawa-Kraków

Rydz E., Jażewicz I. 1994b, Procesy transformacji stupskiego ośrodka przemystowego w latach 19901995, [w:] Funkcjonowanie przedsiębiorstw przemysłowych w zmieniajacych się warunkach gospodarowania, red. Z. Zioło, Wydawnictwo Naukowe WSP, Warszawa-Kraków

Rydz E., Zaleski J. 1992, Stupsk jako ośrodek przemystowy, [w:] Rola i funkcje Stupska na tle sieci osadniczej Środkowego Wybrzeża, Wydawnictwo WSP, Słupsk

Stryjakiewicz T. 1999, Adaptacja przestrzenna przemystu $w$ Polsce $w$ warunkach transformacji, Wydawnictwo UAM, Poznań

Zioło Z. 1997, Problemy transformacji struktur przemyslowych $w$ procesie przechodzenia do gospodarki rynkowej, [w:] Problemy transformacji struktur przemysłowych w procesie przechodzenia do gospodarki rynkowej, red. Z. Zioło, Wydawnictwo Naukowe WSP, Warszawa-Kraków

Zioło Z. 1999, Transformacja struktur subregionalnych Polski potudniowo-wschodniej $w$ procesie zmian systemu gospodarowania, Wydawnictwo PAN, Oddział w Krakowie, Kraków

Zioło Z. 2000, Problemy integracji międzynarodowej przemystu w procesie zmian systemu gospodarowania, [w:] Problemy transformacji struktur przemystowych w procesie przechodzenia do gospodarki rynkowej, red. Z. Zioło, Prace Komisji Geografii Przemysłu PTG, nr 1, Warszawa-Kraków, s. $13-21$

\section{The influence of transformational processes on the local industrial structures on the example of the former Słupsk voivodship}

In the industry of the former Stupsk voivodship, in the period of 1989-2000 substantial changes took place, both quantitative and qualitative, and its future, without any doubt, will depend not only on the possibility of effective local and regional development, but also on the municipal authorities that are responsible for its area's social and industrial development.

As a consequence of the structural changes, there has been a diminution of the cities' role as important centres assembling industrial production potential. The industrial activity has considerably been shifted to the suburban and country areas, where it has found better economic conditions.

After the year of 1992, there have been considerable spatial transformations of industry's division structure. The region's traditional divisions have lost their leading role to the chemical (plastic) and the electromechanical industries. 
During the 1997-2002 period, locational preferences changed. There was an increase in the importance of the following: the cost-factor, institutional support and accessibility of communication. The factor described as business environment, however, was developing in an unsteady fashion, deepening hitherto existing spatial differences.

The privatization process of the state property, the founder's organ of which was the Stupsk voivod, had not been completed till $31^{\text {st }}$ December, 1998. The initiated administration reform did not disturb the processes already in action. The industry's model of privatization in Slupsk voivodship is very characteristic for the general tendency all over the country. 